\title{
An Examination of Factor Influencing on Employee Perception towards Green Human Resource Management
}

\author{
Lakshmikothiswari V., K. Uthayasurian
}

\begin{abstract}
There is a developing requirement for the understanding of environmental administration into (HRM) Green HRM - explores practice. Most of individuals accept that the ability to reproduce nature in the specialized sorts like researcher, architects, legal advisors and lawmakers. Yet, today the workers of associations owe the solidarity to show the green practices which enables them to take part and include themselves in the earth the executive's projects and practices. To keep environmental sustainability in an organization HR functions acts as an important tool to practice. This framework gives better control of company's environmental effects. The scientists led a supposition overview to know the impression of workers on the present consuming concern of Green HRM. The discoveries and consequences are introduced in this paper. The goal of this paper is to gauge and investigate the representative's observation on green human asset the executives rehearses in an association. A self-created poll is utilized as an instrument to gather the data and reaction.
\end{abstract}

Keywords: Green HRM, Green practices, Employee's perception, Environmental sustainability, HR functions.

\section{INTRODUCTION}

In societal concerned regarding an environmental it enhance the organization to cover the management practices in a growth rate. For the requirement of increasing rate organizations are execute an environmental management system (EMS) it acts as major technique utilized in an organization as well as it plays a part of management procedure that requires for organization to recognize the measure and control of their environmental impact [1]. As well as it gives a management system to attained objective for that the companies execute the EMS to enhance the best environmental process for organization impact. To attain the human resources management practices is measured to adopt environmental management practices. [2].

Researchers affirms that a more noteworthy coordination among HRM practices and natural concerns it causes firms to execute EMS adequately. This procedure of help from HR to EM goals is called Green Human Resource Management (GHRM) [3]. Organizations can utilize different individuals management approaches and practices for accomplishing the goal of ecological management. It can deal with the practices of individuals and can add to the green development. It can give a controlling stage to connect with representatives in

Revised Manuscript Received on November 22, 2019.

* Correspondence Author

Lakshmikothiswari V. *, PhD Research Scholar, Department of Commerce, Alagappa University, Karaikudi, Tamil Nadu.

Dr. K. Uthayasurian., Professor, Department of International Business, Alagappa University, Karaikudi, Tamil Nadu. environmentally maintainable manners at work to decrease their carbon impression and implant an eco-accommodating society inside the association. Not many investigations exist in writing to control chiefs in considering the human resource factors so as to augment their activities in effective usage of EMS [4]. Twenty-first century has been indicating uplifted passion for the ecological concerns all around the world regardless of connected field be it governmental issues, open, or business.[5].

Recently The organization frameworks it acts as the major part of organizations. This framework gives better control of association's environmental effects. It incorporates responsibility, approach, arranging, execution, estimation and assessment, audit and improvement of HR frameworks that fit with association's way of life and long haul objectives. From enrollment/on boarding to exit of a representative, Green HR strategies can address each aspect of a worker vocation cycle. The term 'green HR' is regularly used to the commitment of individuals management strategies and practices towards the more extensive corporate environmental motivation. Green HR to utilizing each worker contact direct interface toward advance feasible practices and increment representative mindfulness and duties on the issues of supportability [6]

The context related with the environmental management and human resource management practices among the concept of how green management principles could execute efficiently in an organization which keep growing to determine the involvement of an employee's perception. Many years ago, more researchers agreed with that HRM practices which have the capability to enhance and maintain organizational behavior.

This paper expects to writing in the region, map the area of the field, distinguish a few holes, and recommend some potential productive future examines. The examination likewise addresses the current writing dependent on worker work behaviors and organizational behaviors, explicitly on Organizational Citizenship Behavior (OCB) hypothesis because of certain investigation confinements that uncover the job that Green HRM forms play in human administration frameworks.

\section{IMPORTANCE OF THE STUDY}

Green HR activities assist organizations with discovering substitute approaches to diminish costs without losing their ability in green economy. Organizations have tremendous development openings by making strides toward environmental friendliness and making another natural. As a feature of pay the executives, 
organizations can offer green prizes to representatives.

To considerate regarding why green is shows the significance of green HRM. In this way, greening is basic for the accompanying reasons:

1) To reduce global warming.

2) To diminish ordinary disaster.

3) To depreciate health diseases due to pollution.

4) To reduce harm to animals and other natural creatures.

5) To balance in relatives between environment and life.

6) To confirms endurance of humans and business organization [7].

\subsection{How to Make HRM Functions Green?}

To ensure that the management will get appropriate employees to perform a job, thus the HR functions accommodate or change to be green. It has basically 18 functions such as HRM including job design, safety management,induction , pay management, selection discipline management, grievance management hiring, training and development, career management, incentives management, welfare management, management of employee movements, , health and, job analysis ,performance evaluation, recruitment ,human resource planning, and labor relations.

"To confirms that appropriate employee on green inputs and suitable employee for green performance for job to develop a HRM functions includes practices, procedures and policies."

\begin{tabular}{|c|c|}
\hline Table 1: Green Human resource management functions \\
\hline Functions & Descriptions \\
\hline Job analysis & $\begin{array}{c}\text { It has job description to involve } \\
\text { the dimensions. To include } \\
\text { environmental dimension as a } \\
\text { duty in job description. }\end{array}$ \\
- In job specifications the main \\
element is competencies.
\end{tabular}

\begin{tabular}{|c|c|}
\hline Training & $\begin{array}{c}\text { To import the accurate } \\
\text { information towards greening } \\
\text { for every employees through } \\
\text { program and training to design } \\
\text { GHRM. }\end{array}$ \\
\hline Performance & $\begin{array}{c}\text { To recognize the GHRM } \\
\text { employees and they must } \\
\text { trained. }\end{array}$ \\
\hline Revaluation & $\begin{array}{c}\text { To evaluate employee's job } \\
\text { performance according to } \\
\text { green-related criteria. }\end{array}$ \\
\hline Management & $\begin{array}{l}\text { To give monetary motivating } \\
\text { forces to employees for their } \\
\text { great green presentation of } \\
\text { occupation and non-budgetary } \\
\text { rewards, for example, acclaim } \\
\text { and acknowledgment to } \\
\text { employees for their greening. }\end{array}$ \\
\hline
\end{tabular}

\subsection{OBJECTIVES OF THE STUDY}

1. To investigate an employee perceptions towards green HRM.

2. To associate the demographic factors with the perceptions of employees concerning green HRM in selected units.

3. To provide onward certain suggestions and conclusions have been inwards.

\subsection{HYPOTHESES}

$\mathbf{H}_{\mathbf{0}}$ 1: There is no association between the perceptions of employees on Green HRM practices and education.

$\mathbf{H}_{\mathbf{0}}$ 2: There is no association between the perceptions of employees on Green HRM practices and experience

\section{LITERATURE REVIEW}

1. (Dutta, 2012). GHRM is a pronouncement which makes green workforce that can comprehend and acknowledge green culture in an organization. Such green activity can keep up its green goals all through the HRM procedure of enrolling, employing and preparing, redressing, creating, and propelling the association's human capital [8].

2. Huslid (1995) makes reference to the selection forms, motivator pay, execution the executives frameworks, the representative inclusion, and preparing to be vital for the organization's prosperity. Selecting applicants with green twist of mind make it simple for firms to enlist experts who know with manageable procedures and are now acquainted with nuts and bolts like reusing, preservation, and making an increasingly intelligent world [9].

3. Grolleau et al. (2012) in their examination on effect of natural principles of an organization on Recruitment of an employee found that ecological duty of the organization adds to profile of an organization. In their essential overview, they found that experts were progressively worried about 
regard to the environmental system of an organization [10].

4. Jackson et al. (2011) The most significant part of PM is execution evaluation. Notwithstanding meeting the criteria of reliability, legitimacy, and reasonableness, viable execution examinations give valuable criticism to representatives and bolster ceaseless enhancements in the organization's natural results [11].

5. Renwick et al. (2013) recommends that future research on green execution evaluation should center upon issues, for example, environmental circumstances, environmental duties, correspondence of environmental approach, and green data framework and review [12].

6. Pavitra Mishra (2017) completed an examination to comprehend the status of GHRM rehearses in the Indian Manufacturing division and to investigate factors that may empower Green behaviors. The discoveries propose that the associations have certain current acts of GHRM, yet these practices are neither officially composed under GHRM activities nor persistently pursued. It further uncovers however there are examples of associations endeavoring endeavors to build mindfulness through casual methods, just a couple of gave ecological preparing. If there should be an occurrence of enlistment and choice, associations are just rehearsing utilization of online entrances and web based life. In the event of performance appraisal, there is no specific point about green behaviors [13]

7. According to Candice Harris and Dr. Helen Tregidga (2008), Large number of organizations have vastly move into field of sustainability of employees, some of them are concentrated on job ,impact and HR capacity and administrators. As well as HR directors are characterizing and sanctioning Corporate Sustainability. To develop the demonstration of HR chief uphold private better place for environmental activity in their own lives are restricted [14].

8. On other hand John Sullivan (2009), in his paper has expressed that environmental issues are on practically every one's psyche so if your firm has an upper hand around there will make a business brand. Green enlisting is an opportunity to separate in a selecting commercial center where standing apart from the group is as of now very troublesome. In addition Gen y is concentrating on the Green Recruitment [15].

Table 2: Summarization of Review

\begin{tabular}{|c|c|c|c|}
\hline Sl.no & Title & Author \& year & Technique \\
\hline 1 & $\begin{array}{l}\text { Greening people: A strategic } \\
\text { dimension. }\end{array}$ & Dutta, S. (2012). & $\begin{array}{l}\text { GHRM is used to develop green labor force which } \\
\text { could recognize and comprehend the green culture } \\
\text { in an organization. }\end{array}$ \\
\hline 2 & $\begin{array}{l}\text { The impact of human resource } \\
\text { Management practices on turnover, } \\
\text { productivity, and Corporate financial } \\
\text { performance. }\end{array}$ & $\begin{array}{l}\text { Huselid, } M . \\
\text { (1995). }\end{array}$ & $\begin{array}{l}\text { To recruiting the candidates and give induction to } \\
\text { them to get awareness with the sustainable } \\
\text { procedure and previously recognizable with the } \\
\text { fundamental such as conservation, recycling and } \\
\text { develop a major logical world. }\end{array}$ \\
\hline 3 & $\begin{array}{l}\text { Green Not (only) for profit: An } \\
\text { empirical examination of the effect Of } \\
\text { environmental-related standards on } \\
\text { employees' } \\
\text { Recruitment }\end{array}$ & $\begin{array}{c}\text { Grolleau, G., } \\
\text { Mzoughi, N., \& } \\
\text { Pekovic, S. (2012). }\end{array}$ & $\begin{array}{l}\text { In order to create an environmental redressed } \\
\text { standard of a company ,thus the recruitment plays } \\
\text { an major role to keep the profile of a company. }\end{array}$ \\
\hline 4 & $\begin{array}{l}\text { State-of-the-art and future directions } \\
\text { For Green Human Resource } \\
\text { Management. Zeitschrift für } \\
\text { Personalforschung }\end{array}$ & $\begin{array}{l}\text { Jackson, S., } \\
\text { Renwick, D., } \\
\text { Jabbour, C. J. C., } \\
\quad \& \text { Muller- } \\
\text { Camen, M. (2011). }\end{array}$ & $\begin{array}{l}\text { In every organization the performance appraisal } \\
\text { acts as an important part in personnel } \\
\text { management. }\end{array}$ \\
\hline
\end{tabular}

9. Research by Suhaimi Sudin (2011), It represents that green administration activities has become a significant factor in forward thing businesses around the globe. Specialists contended that representatives must be propelled enabled and environmentally mindful of greening so as to complete green administration activities. The paper centers around improvement of another model of key Green HRM which incorporates connection between appraisal based HR mediations, environmental administration framework, Green scholarly capital and corporate environmental citizenship [16].

10. Stephen King (2004), expressed that the upcoming process of HRM will be based on development and innovativeness, in nutshell advancement and inventiveness approaches were required towards personal satisfaction, environmental upgrades through the sound, maintainable, dynamic network topic. In synopsis it was said that cash and backing of workers can put HRM making progress toward environmental Sustainability [17].

11. Malt Bolch (2008), in his exploration has said getting the message out regarding Sustainability activities may tumble to more than one office yet human asset assumes a significant job, it is significant for human asset experts to have discussions with representatives and the network everywhere about the indications of environmental activities [18].

12. As per the survey done by Buck Consultants (2009), the Greening of HR Survey analyzes the sorts of environmentally well disposed "green" activities that organizations are using including their workforce and human asset rehearses. The outcomes affirm that organizations are joining and moving in the direction of coordinating various green practices. While the examination's inquiries and results are wide, they allude to a few regions for HR experts to consider in the green space. Over portion of the organizations overviewed have joined environmental administration into business activities and have a proper green program set up or plan to execute one in the following a year [19]. 


\begin{tabular}{|c|l|c|l|}
\hline 5 & $\begin{array}{l}\text { Green Human Resource } \\
\text { Management: A review and } \\
\text { Research agenda }\end{array}$ & $\begin{array}{c}\text { Renwick, D. W.S., } \\
\text { Redman, T., \& } \\
\text { Maguire,S.(2013). }\end{array}$ & $\begin{array}{l}\text { Green performance appraisal must targeted on } \\
\text { some environmental problems ,circumstances } \\
\text {,authority and an announcement of environmental } \\
\text { policy and green information framework. }\end{array}$ \\
\hline 6 & $\begin{array}{l}\text { Green HRM: Innovative Approach in } \\
\text { Indian Public Enterprise }\end{array}$ & $\begin{array}{c}\text { R.K.Mishra et } \\
\text { al.,(2014) }\end{array}$ & $\begin{array}{l}\text { In this study it identifies certain presented GHRM } \\
\text { practices instead of that it also targeted on neither } \\
\text { practices properly neither structured under GHRM } \\
\text { neither drives nor elegantly followed. }\end{array}$ \\
\hline 7 & $\begin{array}{l}\text { HR managers and Environmental } \\
\text { Sustainability : Strategic leaders or } \\
\text { passive observers }\end{array}$ & $\begin{array}{l}\text { Candice Harris } \\
\text { and Dr. Helen } \\
\text { Tregidga (2008), }\end{array}$ & $\begin{array}{l}\text { All the employee must be participate on the all the } \\
\text { HR functions in an organization to enhance the } \\
\text { green human resource management. }\end{array}$ \\
\hline 9 & $\begin{array}{l}\text { Fairness of and satisfaction with } \\
\text { performance appraisal process }\end{array}$ & $\begin{array}{l}\text { Suhaimi } \\
\text { sudin(2011) }\end{array}$ & $\begin{array}{l}\text { Researchers contend that the employees must be } \\
\text { inspired and aware to get the management } \\
\text { initiatives. }\end{array}$ \\
\hline Speaking green & $\begin{array}{l}\text { In every organization the human resource } \\
\text { professional acts a vital part to reduce the } \\
\text { employee retention in an organization as well as to } \\
\text { sustain them. }\end{array}$ \\
\hline
\end{tabular}

\section{METHODOLOGY OF THE STUDY}

Top accomplish the objectives thus the data are evaluated from two ways primary and secondary source of data. With the help of questionnaire and pre-structured information the data are gathered from the respondents is known as primary source of data. By the utilization of books, journals, periodicals some data are composed by the use of secondary source of data.

\subsection{MATERIALS AND METHODS}

In this research study both quantitative and qualitative data has been taken. The most pre-dominated variations among the methods are quantitative is represented in numerical way as well as it examined the hypothesis and identify the association among the variables thus the actual work has been carried out. In qualitative method it was done in during the process of research work. 'Employees behavior on Green Human Resource Management Practices' and for investigating the conduct creating speculation and testing are significant and utilizing measurable devices are obligatory, Primarily quantitative research strategy is utilized and subjective technique is additionally presented. Distinct insights and calculated relapse strategy applied in this investigation individually to know the impression of employees about Green HRM and to distinguish the huge components that affected on employees recognition about Green HRM.

\subsection{RESEARCH DESIGN}

\section{A CASE STUDY}

In this study Random sampling technique is used for survey on 100 respondents. It is proposed to undertake the study in Puducherry region. Since the study mainly aims at employee perception on green HRM practices, the study mainly focuses the organizations that practice HRM practices in Puducherry region, namely, HCL, ITC Limited, Integra, WIPRO, SULCON and FORD. Among these companies, it is proposed to undertake the study in two major organizations (HCL and ITC Limited a kind of service and manufacturing organizations respectively.

\section{Technique of Data Analysis}

SPSS version 16 package is utilized for collecting the data. In order to measure the appropriate result from the respondent ANOVA and Chi-square test was evaluated, Reliability and internal consistency was analyzed through coefficient alpha.

\section{FINDINGS AND ANALYSIS}

\subsection{Reliability and Validity}

To calculate the reliability of the research work Cronbach's alpha technique is used. The value of alpha $(\alpha)$ must be larger than 0.70 to imply reliability. Validity measures important variables and elements based on the aim and objective of the study.

Table 3: Reliability Test

\begin{tabular}{|l|c|}
\hline \multicolumn{1}{|c|}{ Name of Variable } & Cronbach's $\boldsymbol{\alpha}$ \\
\hline $\begin{array}{l}\text { An Impact of employee } \\
\text { perception on GHRM }\end{array}$ & 0.862 \\
\hline
\end{tabular}

It is identified from the above table that all the reliability statistical values crossed the required basic criteria and is larger than 0.70 so the reliability values indicate validity for further analysis. Hence it is guaranteed that the study's measurement on reliability and validity is consistent to further analysis.

\subsection{CHI-SQUARE TEST}

Table 4: Chi-Square test on Education of the Employees

\begin{tabular}{|l|c|c|c|}
\hline \multicolumn{1}{|c|}{ Practices } & $\begin{array}{c}\text { Chi-square } \\
\text { value }\end{array}$ & $\begin{array}{c}\text { Degree of } \\
\text { freedom }\end{array}$ & $\begin{array}{c}\text { Statistical } \\
\text { Significance }\end{array}$ \\
\hline $\begin{array}{l}\text { Selection and } \\
\text { Recruitment }\end{array}$ & $\chi^{2}=16.480$ & $\mathrm{Df}=12$ & $\mathrm{P}=21.03$ \\
\hline $\begin{array}{l}\text { Training and } \\
\text { Development }\end{array}$ & $\chi^{2}=4.670$ & $\mathrm{Df}=6$ & $\mathrm{P}=12.59$ \\
\hline $\begin{array}{l}\text { Performance } \\
\text { evaluation }\end{array}$ & $\chi^{2}=20.349$ & $\mathrm{Df}=6$ & $\mathrm{P}=12.59$ \\
\hline
\end{tabular}




\begin{tabular}{|l|c|c|c|}
\hline Promotion & $\chi^{2}=18.671$ & $\mathrm{Df}=6$ & $\mathrm{P}=12.59$ \\
\hline $\begin{array}{l}\text { Organizational } \\
\text { Commitment }\end{array}$ & $\chi^{2}=15.256$ & $\mathrm{Df}=6$ & $\mathrm{P}=12.59$ \\
\hline
\end{tabular}

From the table 4 an analysis of employee's perception on green human resource management practices by education of the employee, it is inferred that the calculated value of selection and recruitment is 16.480 for the degrees of freedom 12 and the tabulated value (21.03) which is greater than the calculated value .Hence, $\mathrm{H} 0$ is accepted .The calculated value of training and development is 4.670 for the degrees of freedom 6 and the tabulated value (12.59) which is greater than the calculated value .Hence, H0 is accepted. The calculated value of performance evaluation is 20.349 for the degrees of freedom 6 and the tabulated value (12.59) which is lesser than the calculated value .Hence, $\mathrm{H} 0$ is rejected. The calculated value of promotion is 18.671 for the degrees of freedom 6 and the tabulated value (12.59) which is lesser than the calculated value .Hence, $\mathrm{HO}$ is rejected. The calculated value of organizational commitment is $\mathbf{1 5 . 2 5 6}$ for the degrees of freedom 6 and the tabulated value (12.59) which is lesser than the calculated value .Hence, $\mathrm{H} 0$ is rejected.

Table 5: Chi-Square test on Experience of the Employees

\begin{tabular}{|c|c|c|c|}
\hline Practices & $\begin{array}{c}\text { Chi-square } \\
\text { value }\end{array}$ & $\begin{array}{c}\text { Degree } \\
\text { of } \\
\text { freedom }\end{array}$ & $\begin{array}{c}\text { Statistical } \\
\text { Significance } \\
(\mathbf{0 . 0 5})\end{array}$ \\
\hline Selection and & $\chi^{2}=7.527$ & $\mathrm{Df}=8$ & $\mathrm{P}=15.51$ \\
\hline
\end{tabular}

\begin{tabular}{|l|c|c|c|}
\hline Recruitment & & & \\
\hline $\begin{array}{l}\text { Training and } \\
\text { Development }\end{array}$ & $\chi^{2}=18.408$ & $\mathrm{Df}=8$ & $\mathrm{P}=15.51$ \\
\hline $\begin{array}{l}\text { Performance } \\
\text { evaluation }\end{array}$ & $\chi^{2}=10.925$ & $\mathrm{Df}=8$ & $\mathrm{P}=15.51$ \\
\hline Promotion & $\chi^{2}=15.782$ & $\mathrm{Df}=8$ & $\mathrm{P}=15.51$ \\
\hline $\begin{array}{l}\text { Organizational } \\
\text { Commitment }\end{array}$ & $\chi^{2}=13.816$ & $\mathrm{Df}=16$ & $\mathrm{P}=15.51$ \\
\hline
\end{tabular}

Findings from the table 5: it is inferred that the calculated value of selection and recruitment is 7.527 for the degrees of freedom 8 and the tabulated value (15.51) which is greater than the calculated value .Hence, $\mathrm{H} 0$ is accepted. The calculated value of training and development is 18.408 for the degrees of freedom 8 and the tabulated value (15.51) which is lesser than the calculated value .Hence, $\mathrm{H} 0$ is rejected. The calculated value of performance evaluation is 10.925 for the degrees of freedom 8 and the tabulated value (15.51) which is greater than the calculated value .Hence, $\mathrm{H} 0$ is accepted. The calculated value of promotion is 15.782 for the degrees of freedom 8 and the tabulated value (15.51) which is lesser than the calculated value .Hence, $\mathrm{H} 0$ is rejected. The calculated value of organizational commitment is 13.816 for the degrees of freedom 16 and the tabulated value (26.30) which is greater than the calculated value Hence, $\mathrm{HO}$ is accepted.

\subsection{ANOVA TEST}

Table 6: Chi-Square test Green HRM Practices by Education of the Employees

\begin{tabular}{|c|c|c|c|c|c|c|}
\hline \multicolumn{7}{|c|}{ ANOVA } \\
\hline & & $\begin{array}{c}\text { Sum of } \\
\text { Squares }\end{array}$ & df & $\begin{array}{c}\text { Mean } \\
\text { Square }\end{array}$ & $\mathbf{F}$ & Sig. \\
\hline $\begin{array}{l}\text { Selection and } \\
\text { Recruiting }\end{array}$ & $\begin{array}{c}\text { Between Groups } \\
\text { Within Groups } \\
\text { Total }\end{array}$ & $\begin{array}{c}26.057 \\
108.268 \\
134.325\end{array}$ & $\begin{array}{c}4 \\
115 \\
119\end{array}$ & $\begin{array}{c}6.514 \\
.941\end{array}$ & 6.919 & $\begin{array}{c}.00 \\
0\end{array}$ \\
\hline E- Filing & $\begin{array}{c}\text { Between Groups } \\
\text { Within Groups Total }\end{array}$ & $\begin{array}{c}8.859 \\
113.466 \\
122.325\end{array}$ & $\begin{array}{c}4 \\
115 \\
119\end{array}$ & $\begin{array}{r}2.215 \\
.987\end{array}$ & 2.245 & $\begin{array}{c}.06 \\
8\end{array}$ \\
\hline Paperless Office & $\begin{array}{c}\text { Between Groups } \\
\text { Within Groups } \\
\text { Total }\end{array}$ & $\begin{array}{l}10.011 \\
53.981 \\
63.992\end{array}$ & $\begin{array}{c}4 \\
115 \\
119\end{array}$ & $\begin{array}{c}2.503 \\
.469\end{array}$ & 5.332 & $\begin{array}{c}.00 \\
1\end{array}$ \\
\hline Car Sharing & $\begin{array}{c}\text { Between Groups } \\
\text { Within Groups Total }\end{array}$ & $\begin{array}{r}13.605 \\
90.320 \\
103.925\end{array}$ & $\begin{array}{c}4 \\
115 \\
119\end{array}$ & $\begin{array}{c}3.401 \\
.785\end{array}$ & 4.331 & $\begin{array}{c}.00 \\
3\end{array}$ \\
\hline Job Sharing & $\begin{array}{c}\text { Between Groups } \\
\text { Within Groups } \\
\text { Total }\end{array}$ & $\begin{array}{c}16.026 \\
89.441 \\
105.467\end{array}$ & $\begin{array}{c}4 \\
115 \\
119\end{array}$ & $\begin{array}{c}4.006 \\
.778\end{array}$ & 5.151 & $\begin{array}{c}.00 \\
1\end{array}$ \\
\hline Teleconferencing & $\begin{array}{c}\text { Between Groups } \\
\text { Within Groups } \\
\text { Total }\end{array}$ & $\begin{array}{r}11.666 \\
95.326 \\
106.992\end{array}$ & $\begin{array}{c}4 \\
115 \\
119\end{array}$ & $\begin{array}{c}2.916 \\
.829\end{array}$ & 3.518 & $\begin{array}{c}.01 \\
0\end{array}$ \\
\hline Recycling & $\begin{array}{c}\text { Between Groups } \\
\text { Within Groups Total }\end{array}$ & $\begin{array}{c}5.833 \\
155.159 \\
160.992 \\
\end{array}$ & $\begin{array}{c}4 \\
115 \\
119 \\
\end{array}$ & $\begin{array}{l}1.458 \\
1.349\end{array}$ & 1.081 & $\begin{array}{c}36 \\
9\end{array}$ \\
\hline Telecommuting & $\begin{array}{c}\text { Between Groups } \\
\text { Within Groups } \\
\text { Total }\end{array}$ & $\begin{array}{r}3.052 \\
88.148 \\
91.200\end{array}$ & $\begin{array}{c}4 \\
115 \\
119\end{array}$ & $\begin{array}{l}.763 \\
.767\end{array}$ & .995 & $\begin{array}{c}.41 \\
3\end{array}$ \\
\hline Online Training & $\begin{array}{c}\text { Between Groups } \\
\text { Within Groups Total }\end{array}$ & $\begin{array}{r}66.629 \\
187.162 \\
253.792 \\
\end{array}$ & $\begin{array}{c}4 \\
115 \\
119\end{array}$ & $\begin{array}{r}16.657 \\
1.627\end{array}$ & 10.235 & \\
\hline
\end{tabular}


An Examination of Factor Influencing on Employee Perception towards Green Human Resource Management

\begin{tabular}{|c|c|c|c|c|c|c|}
\hline Green rewards & Between Groups & 2.708 & 4 & .677 & 1.018 & .40 \\
& Within Groups & 76.492 & 115 & .665 & & 1 \\
& Total & 79.200 & 119 & & & \\
\hline Energy efficient & Between Groups & 21.597 & 4 & 5.399 & 2.830 & .02 \\
Office space & Within Groups & 219.395 & 115 & 1.908 & & 8 \\
& Total & 240.992 & 119 & & & \\
\hline Virtual & Between Groups & 88.986 & 4 & 22.246 & 16.096 & .00 \\
Interviews & Within Groups Total & 158.939 & 115 & 1.382 & & 0 \\
& & 247.925 & 119 & & & \\
\hline
\end{tabular}

It is observed that E-Filing, Recycling, Telecommuting there is no significant difference in perceptions of the employees by Education and the rest of the variables has significantly associated with the means. Finally, it was interpret it has influence on the GHRM practices.

Table 7: Chi-Square test Green HRM Practices by Education of the Employees

\begin{tabular}{|c|c|c|c|c|c|c|}
\hline \multicolumn{7}{|c|}{ ANOVA } \\
\hline & & $\begin{array}{c}\text { Sum of } \\
\text { Squares }\end{array}$ & df & $\begin{array}{r}\text { Mean } \\
\text { Square }\end{array}$ & F & Sig. \\
\hline $\begin{array}{l}\text { Selection and } \\
\text { Recruiting }\end{array}$ & $\begin{array}{c}\text { Between Groups } \\
\text { Within Groups } \\
\text { Total }\end{array}$ & $\begin{array}{c}8.563 \\
125.762 \\
134.325\end{array}$ & $\begin{array}{c}4 \\
115 \\
119\end{array}$ & $\begin{array}{l}2.141 \\
1.094\end{array}$ & 1.957 & .106 \\
\hline E- Filing & $\begin{array}{c}\text { Between Groups } \\
\text { Within Groups Total }\end{array}$ & $\begin{array}{c}7.192 \\
115.133 \\
122.325\end{array}$ & $\begin{array}{c}4 \\
115 \\
119\end{array}$ & $\begin{array}{l}1.798 \\
1.001\end{array}$ & 1.796 & .134 \\
\hline Paperless Office & $\begin{array}{c}\text { Between Groups } \\
\text { Within Groups Total }\end{array}$ & $\begin{array}{c}1.191 \\
62.801 \\
63.992\end{array}$ & $\begin{array}{c}4 \\
115 \\
119\end{array}$ & $\begin{array}{l}.298 \\
.546\end{array}$ & .545 & .703 \\
\hline Car Sharing & $\begin{array}{c}\text { Between Groups } \\
\text { Within Groups } \\
\text { Total }\end{array}$ & $\begin{array}{c}1.588 \\
102.337 \\
103.925 \\
\end{array}$ & $\begin{array}{c}4 \\
115 \\
119 \\
\end{array}$ & $\begin{array}{l}.397 \\
.890\end{array}$ & .446 & .775 \\
\hline Job Sharing & $\begin{array}{c}\text { Between Groups } \\
\text { Within Groups Total }\end{array}$ & $\begin{array}{c}10.280 \\
95.187 \\
105.467\end{array}$ & $\begin{array}{c}4 \\
115 \\
119\end{array}$ & $\begin{array}{c}2.570 \\
.828\end{array}$ & 3.105 & .018 \\
\hline Teleconferencing & $\begin{array}{c}\text { Between Groups } \\
\text { Within Groups Total }\end{array}$ & $\begin{array}{c}5.943 \\
101.049 \\
106.992 \\
\end{array}$ & $\begin{array}{c}4 \\
115 \\
119 \\
\end{array}$ & $\begin{array}{c}1.486 \\
.879\end{array}$ & 1.691 & .157 \\
\hline Recycling & $\begin{array}{c}\text { Between Groups } \\
\text { Within Groups } \\
\text { Total } \\
\end{array}$ & $\begin{array}{c}16.318 \\
144.673 \\
160.992 \\
\end{array}$ & $\begin{array}{c}4 \\
115 \\
119 \\
\end{array}$ & $\begin{array}{l}4.080 \\
1.258\end{array}$ & 3.243 & .015 \\
\hline Telecommuting & $\begin{array}{c}\text { Between Groups } \\
\text { Within Groups Total }\end{array}$ & $\begin{array}{l}14.248 \\
76.952 \\
91.200 \\
\end{array}$ & $\begin{array}{c}4 \\
115 \\
119 \\
\end{array}$ & $\begin{array}{c}3.562 \\
.669\end{array}$ & 5.323 & .001 \\
\hline Online Training & $\begin{array}{c}\text { Between Groups } \\
\text { Within Groups } \\
\text { Total } \\
\end{array}$ & $\begin{array}{c}14.363 \\
239.429 \\
253.792 \\
\end{array}$ & $\begin{array}{c}4 \\
115 \\
119 \\
\end{array}$ & $\begin{array}{l}3.591 \\
2.082\end{array}$ & 1.725 & .149 \\
\hline Green rewards & $\begin{array}{r}\text { Between Groups } \\
\text { Within Groups Total }\end{array}$ & $\begin{array}{c}8.770 \\
70.430 \\
79.200\end{array}$ & $\begin{array}{c}4 \\
115 \\
119 \\
\end{array}$ & $\begin{array}{l}2.193 \\
.612\end{array}$ & 3.580 & .009 \\
\hline $\begin{array}{c}\text { Energy efficient } \\
\text { Office space }\end{array}$ & $\begin{array}{l}\text { Between Groups } \\
\text { Within Groups Total }\end{array}$ & $\begin{array}{c}23.614 \\
217.377 \\
240.992 \\
\end{array}$ & $\begin{array}{c}4 \\
115 \\
119 \\
\end{array}$ & $\begin{array}{l}5.904 \\
1.890\end{array}$ & 3.123 & .018 \\
\hline Virtual Interviews & $\begin{array}{c}\text { Between Groups } \\
\text { Within Groups } \\
\text { Total } \\
\end{array}$ & $\begin{array}{c}4.635 \\
243.290 \\
247.925 \\
\end{array}$ & $\begin{array}{c}4 \\
115 \\
119 \\
\end{array}$ & $\begin{array}{l}1.159 \\
2.116\end{array}$ & .548 & .701 \\
\hline
\end{tabular}

In which thus the above variable E- Recruiting, E- Filing, Paperless Office, Car Sharing, Teleconferencing, Online Training, and Virtual Interviews, there is a significant difference in perceptions of the employees by Experience. Finally it discussed that it has no influence of the experience on the employee's behavior.

\section{FINDINGS OF THE STUDY}

- In chi square test: Green HRM Practices by Education of the Employee's perception the majority of the variables are 
significant association with the GHRM practices.

- Green HRM Practices by experience of the Employee's perception the majority of the variables are significant association with the GHRM practices.

- In ANOVA test it was inferred experiences of the employees are not significantly influence as well as education is significantly influences with the practices.

- High aspect for GHRM rehearses and critical impact of demographical factors unmistakably demonstrating that exceptionally taught and senior workers have better information on GHRM rehearses. Along these lines, they firmly prescribed GHRM rehearses, however because of less awareness others reacted in an unexpected way.

\section{SUGGESTIONS}

The organization needs to lead awareness projects and training programs likewise ought to be led with this respect. Worker training and development software engineers ought to incorporate social and ecological issues at all levels, from specialized wellbeing and security contemplations on the shop floor, to vital maintainability issues at official management and board level. Training is a key intercession to oversee squander (regarding both aversion and decrease), and happens through associations training groups of cutting edge representatives to create a waste examination of their work regions. It is recommended that green groups can be built up in every division, delivering general awareness and explicit training.

\section{CONCLUSION}

Green practices and strategies are currently deliever their path towards human resource space with the help of present green practices and activities. GHRM performance is carried from elaborated effectiveness, cost decreases, enhancing profitability, representative maintenance rather than unmistakable merits. The businesses and professionals can build up the convenience of connecting worker inclusion and cooperation in ecological management projects to improved hierarchical natural execution, as with a particular spotlight on making green items. The green HRM activities brings about expanded efficiencies, feasible utilization of assets, less wastage, improved employment related frame of mind, improved work life balance, improved nature of work life by the mean of GHRM.

\section{REFERENCES}

1. Bansal, P. Hunter T. 2003. Strategic explanations for the early adoption of ISO 14001. Journal of Business Ethics, 46(3): 289-299.

2. Govindarajulu, N. and Daily, B. F.(2004), "Motivating Employees for Environmental Improvement", Industrial Management and Data Systems, Vol. 104, pp. 364-372

3. Renwick et al(2008)“Green HRM: A review, process model, and research agenda", Discussion Paper Series, University of Sheffield Management School, The University of Sheffield

4. Wee, Y.S. and Quazi, H.A. (2005), "Development and validation of critical factors of environmental management”, Industrial Management \& Data Systems, Vol. 105 No. 1, pp. 96-114.

5. Victor, D. G. (2001). The collapse of the Kyoto Protocol and the struggle to slow global warming. Princeton, NJ: Princeton University Press.
6. Wirtenberg, J., Harmon, K. D., Russell, W. G., \& Fairfield, K. D. (2007) HR's role in building a ustainable enterprise. Human Resource Planning, 30, 10-20.

7. Certo, S.C., \& Certo, S. T. (2008) Modern management. USA:Pearson Education

8. Dutta, S. (2012). Greening people: A strategic dimension. ZENITH: International Journal of Business Economics \& Management Research, 2, 143-148.

9. Huselid, M. (1995). The impact of human resource management practices on turnover, productivity, and corporate financial performance. Academy of Management Journal, 38, 635-672.

10. Grolleau, G., Mzoughi, N., \& Pekovic, S. (2012). Green not (only) for profit: An empirical examination of the effect of environmental-related standards on employees' recruitment. Resource and Energy Economics, 34, 74-92.

11. Jackson, S., Renwick, D., Jabbour, C. J. C., \& Muller- Camen, M (2011). State-of-the-art and future directions for Green Human Resource Management. Zeitschrift für Personalforschung: German Journal of Research in Human Resource Management, 25, 99-116.

12. Renwick, D. W.S., Redman, T., \& Maguire, S. (2013).Green Human Resource Management: A review and research agenda. International Journal of Management Reviews, 15(1), 1-14. ijmr.2013.15.issue-1

13. R.K.Mishra et al., Green HRM: Innovative Approach in Indian Public Enterprises, World Review of Science, Technology and Sustainable Development, 11(1), 2014, 26-42.

14. Candice Harris and Dr. Helen Tregidga (2008),HR managers and Environmental Sustainability : Strategic leaders or passive observers, Track management.

15. JD Sullivan - Focus, 2009 - documents.worldbank.org 16. Suhaimi Sudin(2011), fairness of and satisfaction with performance appraisal process, 2 nd international conference on business and economic research (2nd icber 2011) proceeding.

16. Kanika Sharma, Conceptualization of Green HRM and Green HRM Practices: Commitment to Environment Sustainability, International Journal of Advanced Scientific Research and Management, Vol. 1 Issue 8, August 2016.

17. Malt Bolch (2008), Speaking Green, HR magazine.

18. http://dx.doi.org/10.1111/ 